\title{
For an Analysis of Autonomia: An Interview with Sergio Bologna ${ }^{1}$
}

\section{Patrick Cuninghame}

Sergio Bologna, ${ }^{2}$ as one of the leading intellectuals of the Italian "operaism" (workerism) ${ }^{3}$ Marxist current, has maintained a sympathetic but critical stance towards the social movements of autonomous workers, self-organised students, radical feminists and counter-cultural youth that made up Autonomia (Autonomy) in the 1970s. His essay on the 1977 Movement (in which Autonomia was one of the main protagonists), "The Tribe of Moles," provides one of the most complete analyses of the social, political and economic origins and composition of one of Italy's most important mass political and social movements, the roots of the present widespread network of centri sociali (squatted social centres) and free radio stations.

The term "Autonomia" is itself ambiguous since it refers to two interconnected but quite separate phenomena. On the one hand, Autonomia Operaia (AO, Workers Autonomy, also known as Autonomia Organizzata, Organised Autonomy), as the name implies, was a direct descendent of the operaist tradition, stemming from the seminal Quaderni Rossi (QR, Red Notebooks) journal of the early 1960s. This was the project of various dissident PCI and PSI intellectuals to theorise, through a reinterpretation of Marx's "workers' enquiry," the "class composition" and "self-valorisation" of the "mass worker" (see note 15) present in the upsurge in autonomous working class militancy during the "Economic Miracle" and mass internal migration from South to North from the mid 1950s onwards. Italian workerism began to emerge as a political and intellectual movement which held to the PCI's tenet of "workers centrality" but was otherwise critical of orthodox Marxism's victimist vision of the working class and the ineffectual reformism of the Historical Left. From this initiative, via Classe Operaio (a more activist version of QR), Potere Operaio Veneto-Emiliano 4 (a regional group and newspaper dedicated to factory struggles in NE Italy) and through various local factory initiatives, particularly in the Porto Maghera chemical plant, was born the national political organisation Potere Operaio (PO, Workers Power) in 1969. PO was instrumental in pushing for an alliance between the libertarian 1968 students' movement and the widespread autonomous workers movement of what became the Hot Autumn of 1969. It dissolved itself in 1973, pressured from one side by the resurgence of feminism which caused a crisis of militancy and the withdrawal of many women activists from the masculinist post-1968 Marxist groups such as PO, Lotta Continua (LC, Fight On) ${ }^{5}$ and Avanguardia Operaia (Workers' Vanguard). The redundancies and restructuring triggered by the 1973 Oil Crisis allowed the PCI and trade unions to regain control of the large factories of the 
Northern industrial triangle and so undermined the presence of $\mathrm{PO}$ and the other "groups" within the factories, so crucial to their legitimacy and raison d'être. At the same time, the peak of autonomous factory militancy, the wild cat strike and occupation of the FIAT Mirafiori plant in Turin in March 1973, demonstrated their redundancy as few of the "fazzoletti rossi" (red bandannas used to hide their identity during internal factory demonstrations and "spazzolate" [sweepings] against scabs, foremen and managers) were New Left activists.

Autonomia Operaia emerged as a less structured network of local factory and social collectives in the mid 1970 s, bound together by "free" radio stations like Rome's Radio Onda Rossa and Padua's Radio Sherwood, as well as publications such as Rosso in Milan, Senza Tregua in Rome, and Primo Maggio in Turin. Here again mainly male intellectuals, such as Toni Negri and Oreste Scalzone, debated the emergence of a new social subject from the struggles of the early 1970 s, the "operaio sociale" (socialised worker, see note 15) situated in the open spaces of the "social factory," whereas the "operaio massa" (mass worker) had been limited to industrial factory struggles. Relations with the feminist movement continued to be tense and autonomous ${ }^{6}$ women's collectives were critical of AO's continuance of some discredited forms of political practice from the groups, particularly a macho predisposition to the use of (sometimes armed) violence. At the same time, these autonomous women were accused of being more old-style Marxist revolutionaries than feminists by "consciousness raising" feminism and so isolated from the mainstream women's movement. AO's attempt to hegemonise and organise the counter-cultural and post-political 1977 Movement also met with considerable opposition. The Red Brigades' (RB) 1978 kidnapping and killing of Aldo Moro, senior Christian Democrat statesman and chief interlocutor with the PCI in their common project of an "Historical Compromise,"7 legitimised draconian state repression, provoking a general "riflusso" (withdrawal into private life) from political activism, pushing the most radical sections of AO to call for an "intensification" of the class struggle through armed struggle and industrial sabotage. This in turn allowed the state to arbitrarily equate $\mathrm{AO}$ with the $\mathrm{RB}$, resulting in the mass arrests of AO's vulnerable intellectuals on April 7 1979, despite their bitter criticisms of the RB's "anachronistic, counterproductive and militarist" attempt to topple the State and seize power. The resulting witch hunt of Autonomist intellectuals and activists, orchestrated by magistrates and journalists close to the PCI in particular, resulted in various waves of mass arrests, imprisonment on remand for up to five years on terrorism charges, and the exile of the core intellectuals and activists. $\mathrm{AO}$, as an attempted revolutionary neo-Leninist vanguard structure within the broader social revolt, had been smashed by 1983, although its constituent "submerged network" of local groups and individuals survived the bleak political winter of the 1980 s to participate in the consolidation of the network of "centri sociali" (squatted social centres) in the 1990s.

Conversely and confusingly, Autonomia also refers to "diffused" or 
"creative" Autonomia, the "autonomy of the social" represented by the mass of mainly counter-cultural youth, students, unemployed and semi-employed young people, radical feminists, gay men and lesbians, street artists and those disaffected former members of the New Left "groups" who were increasingly critical of dogmatic Marxism, known as "cani sciolti" (stray dogs). Youth and graduate unemployment reached crisis levels in the mid 1970s. Many young people consciously chose to avoid even looking for work (let alone the "refusal" of the late 1960s). Increasingly, they fled from the suffocating authoritarianism of the traditional Italian nuclear family to live collectively, often in squatted houses and flats. They survived partially though "lavori neri" (the growing postFordist sector of precarious, short-term, low paid, deregulated, black market jobs) and partially through mass expropriations of food from supermarkets and restaurants, but also through the "self-reduction" of bus fares, rock concert and cinema tickets. This was the sea in which the fish of AO swam, but it was not necessarily an ideal environment. The irreverent Metropolitan Indians of the 1977 Movement not only mercilessly mocked the institutional Left, but also satirised the excessive seriousness and self-importance of the revolutionary Left, of their very concept and practice of politics, leading some to theorise about the emergence of a "post-political politics." 8 It is important, however, to demythicise the imaginary splits that some sections of the press and the academy have fantasised about, between "peaceful creativi" and "violent autonomi." Despite their diverging political praxis and objectives, there appears to have been considerable interaction between these two types of Autonomia, particularly during the 1977 Movement; further evidence that the division between cultural and political social movements imposed by sociologists such as Melucci ${ }^{9}$ may be more formal than real.

In this interview Bologna outlines an "operaist" methodology for the analysis of the history and class composition of the autonomous workers movements in Italy, based on the interrelation of political elites, intellectuals and mass movements, "spontaneity" and the organisation of microsystems of struggle through three generations of grass-roots political militants, from the 1950 s to the 1980 s.

PC: How can we analyse the history of the Italian social movement of the 1970s, Autonomia?

SB: By using the same methodology we used to analyse the historical phenomena of the European parties and movements of the 1920s and 1930s. We have always tried to distinguish clearly the behaviours and expressions of the history of the political elites (whether ideological or organisational) from those of the spontaneous movements, from that which was a real class composition, of the masses, or of a group, or a neighbourhood, or in a factory, and so on. To try to understand the relationship between these two things, always keeping in mind 


\section{Left History 7.2}

that they are two completely distinct levels. So, I think we should apply the same method to our history. We should try to understand to what extent we, as intellectuals and militants, represented a political elite; that is, a political stratum whose history is substantially entwined with, but is not the same as the history of the movements.

We try sometimes to interpret and sometimes to anticipate. Sometimes we have a greater ability to suggest new perspectives or to give an identity to the movement. But most of the time, I would say, we were the ones receiving an input. Initially, there was an ability, a grass-roots creativity and, therefore, a selforganisational capacity, a consciousness, and above all a knowledge, a political know-how, which set in motion systems of struggle and organisational systems which gave us an input. In other words, a series of aspects of reality were suggested to us and on which we reflected. Simultaneously, a series of subjective behaviours was also suggested, of contemporary cultures, of tensions, of projects, which we might have later tried to ideologise ex-post, or to insert in a broader programme, a wider picture, or even to insert into a network. So, I think the fundamental method is that of always keeping absolutely separate these two poles and to try to identify the dialectic, in the sense that they are two distinct poles. But the real history is a little bit the history of their meetings and partings.

PC: Between the elite and the masses?

SB: No, it's not the masses, and this is an important point. We don't claim that it is possible to talk about the movement as an indistinct phenomenon. For example, the first autonomous, independent, self-organised wildcat strikes, maybe in a single section, at FIAT, Pirelli, Innocenti, ${ }^{10}$ and in all the big factories at the beginning of the $1960 \mathrm{~s}$, were not of the masses. Rather, they were the result of a highly sophisticated political history, of workers cadres and militants who had passed on the inheritance of a certain political culture to workers' groups. And, therefore, they had succeeded in creating systems of struggle, maybe very partial, very local, but which were already politically mature organisms. Thus, when we put ourselves in contact with a mass movement, in reality we are opening a relationship with organisms which are already politically mature. So this completely changes the vision which makes the political elite an active subject and the mass movement a passive subject: the political elite, a kind of stratum endowed with knowledge and, instead, the mass movement, a stratum endowed only with wishes, with desires, with tensions and so on. In reality, the relationship is a dialectical one: the mass movement which is already endowed with knowledge, which already has a rather advanced system of political knowledge, of political know-how, capable of producing systems of struggle which obviously break with the trade unions, with the party, and which can offer us... the beginning of this exchange between intelligentsia and militants. 
In this sense, I think the best teacher of this way of interpreting events is Danilo Montaldi. ${ }^{11}$ The fundamental concept (of this method of research) is this: spontaneity does not exist. What we could call "spontaneity" is, in reality, the formation of microsystems of struggle which are already very mature politically, because they have been determined by a generation of militants who came from the Resistance. Or else, they were worker militants who had already been trade union leaders, who broke individually and gradually, in silence, with the unions, and developed their own autonomy. But they are people, they are a generation and therefore, perhaps, also a kind of political elite, already very mature. So the first rank-and-file committees (comitati di base/CDB) at Pirelli were formed by ex-shop stewards of the $\mathrm{CGIL}^{12}$ and ex-local leaders of the PCI (Italian Communist Party). In fact, Montaldi wrote this beautiful book, entitled Militanti Politici di Base (Grassroots Political Militants), where he wrote the history and the theory of this stratum, of this generation of revolutionary militants, almost all workers, or else linked to peasant struggles. (They) had such a profound political culture, such a profound capacity to set in motion organisational systems, systems of struggle, which, according to Montaldi - this is the part where he is so right - are the real leaven, are the real drive to those struggles which appeared before and during Quaderni Rossi (Red Notebooks). ${ }^{13}$ So, Quaderni Rossi was an attempt to understand these things and to theorise them. However, within Quaderni Rossi, according to Montaldi and also many others, only a few people, in particular Romano Alquati, had the capacity to understand these things, while the others were completely out of touch, in my opinion. They didn't even pose this problem.

\section{PC: And Panzieri?}

SB: Panzieri yes and no, let's say. Above all, it was Alquati who was the representative of this knowledge that there is a sophisticated system of political consciousness at the grassroots level.

So, on this basis we can also analyse Autonomia. What does this mean? It means that we must consider Tony Negri's or Oreste Scalzone's group or Roman Autonomia (i.e., all the part of the movement known as Autonomia Organizzata), as the political elite which intersected with a real movement. And so we should make the history of this real movement (which) is very difficult to do... to separate clearly the elite from the real movement... because the same problems arise as with the movement of the 1950s and 1960s, in the sense that, as then, we can say that there was the presence of this network of grassroots militants, grassroots political activists, with a high level of political know-how, but almost all proletarians. In other words, none of them were intellectuals. They were all in the factory or peasant struggles. We have to see what composition (social, intellectual, political) the 1977 Movement $^{14}$ had, which is not very simple because obviously it was a kind of both synthesis and transcendence of three generations of movements. 


\section{Left History 7.2}

The first generation of these movements was the one I referred to before, from the 1950 s to the middle of the $1960 \mathrm{~s}$. This generation reproduced the type of autonomous workers struggles which were theorised by Quaderni Rossi and by Classe Operaia (Working Class). ${ }^{15}$ From $1966 / 67$ a second generation was formed which became that of 1968 and which did not come from the communist history or tradition, while the first had. With 1967/68 the generation of the New Left was formed; that is, of militants who had learnt the language of antagonism, of revolution, partly from us. And here our role did become important. Our role had not been important during the first phase, of the type of workers struggles which we had theorised from the mid 1950s to the mid 1960s. Our role became important in the movements of 1968, which were not of workers but of students. Then the political elite did play a vanguard role.

The synthesis of all these things was in 1969 when the operaist (workerist) political elite brought a strategy into the 1968 movement which was to win, while other anti-authoritarian elites were effectively defeated and marginalised. It was in 1969 when the whole movement found itself in front of the gates of FIAT that we had won. The victory of the workerist tendency forced the whole of the students' movement to measure itself with workers' struggles. The workerist tendency was much more advanced, stronger from an intellectual viewpoint, (and) it had a greater political know-how because it knew about the workers' struggles, while the other tendencies didn't. So, it succeeded in having a dialogue with the workers' struggles and with the history of the workers' struggles while the others didn't. At this point, also the mass movement, the workers' movement, which had been mobilised by the old political militants, saw (the arrival of) a second generation of workers. Thus, various political generations of workers were formed in the factories.

PC: This would be the "mass worker"?16

SB: Who were exactly the mass workers of 1968 up until 1973 or possibly until 1980. Or even those who still resist today, because this history of real workers' autonomy, of the "comitati di base" (rank-and-file committees), workers of 1968, still exists in some factories, for example in Alfa Romeo in Milan. The leaders of the present CDB of Alfa Romeo are leaders who emerged in 1969/70. So, they are people with a history of twenty to twenty-five years of struggle, who have been sacked five or six times and have been reinstated. They are a political class, but of workers, and not an intelligentsia. They are really mass political leaders to all effects and purposes.

PC: What is the difference between an intelligentsia and self-educated workers?

SB: The intelligentsia, in this case, must always seek a form of mediation. Then later things changed. We're still talking here about the period in which the 
common denominator was that relationship between the workers' movement and the movement of workers' autonomy and the workerist elite, call it what you will. What happened after the great workers' struggles of 1969-73, of that cycle, was something very interesting. Because 1968 in Italy had set in motion a mental revolution throughout various social strata, at the level of various professional functions and vocations. There was a complete transformation (with) struggles inside hospitals, within the field of medicine and so on. Partly also artists and intellectuals. At this point, a large part of the bourgeois class, or if you prefer, the liberal professions such as lawyers and judges, became involved in the movement; for example, there were "democratic judges." 17

Thus, the intelligentsia spread out and became a diffused intelligence, which acted not as a political, Leninist, intelligentsia - this is a vital point to understand - towards the working class. Instead, it acted as a new intelligentsia within the professions. A doctor could set up an assembly, a grassroots committee of doctors and begin to create an alternative medicine, begin struggles against the medical hierarchy, against the pharmaceutical factories and pharmacological medicine, against the hierarchical relationship between doctor and patient. So began this long march within the medical institutions, which was, in my opinion, one of the most interesting aspects of the Italian revolution, and was brought about by Basaglia, ${ }^{18}$ by Maccacaro and Terziamboli. We have the names of great scientists who transformed some aspects, at least for a certain period, of the world of hospital life and Italian medicine. The same thing happened among judges, among lawyers; something among artists but very little, and very little among writers with a few exceptions such as Balestrini. ${ }^{19}$ This was a phenomenon of the greatest importance.

I think the publication which best represented this phenomenon, also of interdisciplinary intellectuals who used their technical knowledge to overturn the whole stance of the capitalist sciences and technology, was the journal Sapere (Knowledge), edited by Maccacaro. I was the only exponent of classical workerism to have participated in this magazine. However, I succeeded, we succeeded, in influencing the magazine's position because we had our own particular vision of technology, of science which was much clearer, much more systematic, if you like. It was the first journal to open an ecological and ambientalist debate in Italy on a scientific basis, completely different from that of the ecologists of the 1980s, because the essential principle of our ecological stance was that ecology begins above all with the exploitation of human labour. For this reason we began with toxicity inside the factory.

One of the protagonists of this struggle within the journal and within the Italian movement was Luigi Marra, a technician from Montedison ${ }^{20}$ in Castellanza, who was a cadre (and)... the most extraordinary figure of the real autonomy of the last twenty years in Italy. He is a laboratory technician who lost both his forearms in a workplace accident (an explosion) and since then has dedicated his whole life to fighting toxicity and other dangers inside the factory. 
He has accumulated a formidable amount of knowledge on this theme, aided by many scientists, physics researchers, biologists and doctors.

In 1976 the ICMESA chemicals factory in Seveso exploded, contaminating a wide area with large amounts of dioxin, a highly toxic substance, and was the first major ecological accident, anticipating Bhopal and Chernobyl. It was the first time public opinion became aware of a possible ecological disaster. None of the scientists sent by the UN and the World Health Organisation realised that the problem was dioxin. For the first week they were stumbling in the dark. Those who discovered that the problem was dioxin were the workers, namely those workers organised by Luigi Marra who, understanding perfectly the chemical processes and the possible accidents that could be caused by these processes, questioned the workers of ICMESA who had not wanted to talk, who were afraid. They succeeded, together with the ICMESA workers, in reconstructing the whole productive cycle, in recounting everything that had happened - What was that valve for and how had it reacted? - and in the end they understood that the only substance that could have been produced by the accident was dioxin. So, (this was a demonstration of) the very highest techno-scientific ability. This was our ecological battle, it wasn't like those shits, the Greens! ${ }^{21}$

And so we arrive at 1975-77. The 1977 Movement was something completely different. It was a new and interesting movement because, firstly, it did not really have roots in previous movements, or else it did, but in a highly complex manner. It clearly had another social basis, different from both 1968 and 1973. It had a social composition based on youth who had broken with or rejected the political elites, including the elites of 1968 , including therefore the groups of Lotta Continua (LC, Fight On) or even of Autonomia Organizzata (Organised Autonomy). So, it broke not only with the traditional communist movement, but also with 1968. It broke exactly with the vision of communism, while, at the end of the day, also the workerists thought of themselves as being the "true communists." The " 77 Movement absolutely did not want to be "truly communist."

\section{PC: And did they still have any intention of "taking power"?}

SB: No, I would say absolutely not. They had no intention of taking power. In this sense, it was the most anti-Leninist movement possible. It did, however, have a very strong collective knowledge. They had read a lot of magazines like Il Sapere and were already a... generation where techno-scientific thought and computing were already playing an important role. The techno-scientific elite counted more than the political elite did within the ' 77 Movement.

What relationship did Autonomia, namely the Negri group, or even Primo Maggio (First of May), ${ }^{22}$ have with this movement compared to all the other Marxist-Leninist, Maoist political elites or groups like LC? Why were we the only ones able to dialogue with the ' 77 Movement? Maybe because we 
succeeded in understanding what was the profound nature of this movement? We succeeded, therefore, in understanding better than the others that this movement broke all the rules and since we had never been much attached to rules ourselves, we could interpret it better than others, understand it or accept it better than others.

PC: Did you have a relationship of leadership with this movement?

SB: Probably someone tried to have one. Certainly Organised Autonomy tried and in Rome perhaps they even succeeded at times. Certainly they succeeded in Padua. Rome and Padua were the only two cities where Organised Autonomy became inseparable from the movement. But in general I would say that as a movement it was something else. Thus, Organised Autonomy, apart from Rome and Padua, represented more of an attempt to interpret, to mould an identity or give prospects, slogans more than anything else did. Primo Maggio was not even a political elite. Rather, we had refused our role as a political elite to put ourselves instead in the role of that techno-scientific intelligentsia which excavated within the disciplines. So, we wanted to excavate within the historical disciplines to make history in another way. You read Primo Maggio and it is not a political journal, in the sense that it is a journal... for the transformation of historical methodology. In the sense of transformation also of historigraphical language which has an enormous importance in political language.

PC: Does postmodernism have something to say as a methodology on analysing Autonomia?

SB: Certainly the ' 77 Movement and several of these intellectuals linked to Autonomia had read Foucault, especially, with great passion. They identified more with Foucault, sometimes, than with Marx or Lenin, and this is obviously very important. A discussion was opened.

Finally, the fundamental point to clarify or to put as an interrogative is: What was Autonomia? What do we understand by Autonomia? What is its definition? Because there is always this danger of misunderstanding Autonomia as a political elite, Autonomia as a new type of political thought, Autonomia as the definition of a mass movement, or what? So, it's very difficult. Where can we begin? I believe the first thing to say is exactly to specify, to articulate these differences, basically between the different levels. As a result, from time to time, we have called Autonomia all three or four of these things together. So, we have to premise that this word, "autonomy," is at the same time a very complex word but also highly ambiguous. What is important is not to create through this ambiguity some major contradictions. Keeping in mind that in fact the thought of Organised Autonomy, in particular the thought of Toni Negri, is a system of thought which in a certain sense has theorised ambiguity. Exactly on this point: 
the relationship between political elites, ideology and movement. This attempt to refuse Leninism, to say essentially that the political forms of today are dynamic political forms which open (and) close, which are not permanent. Obviously, it was a way of hiding, shall we say, the dialectic between political elite and movement. So, you have to be very careful, I think, exactly on this type of specification, otherwise it's a mess. Not only, there is also the danger of taking the Calogero Theorem ${ }^{23}$ and unconsciously reproducing it. Calogero overdetermined and enormously exaggerated the role of Organised Autonomy, radically overturning the historical relationship, by claiming: "Autonomia is responsible for all this." History (shows) exactly the opposite: all this explains Organised Autonomy and not the other way round. Therefore, if we do not pay attention to this distinction, implicitly, unconsciously, we are reproducing the Calogero Theorem.

1 This interview was conducted in June 1995 in Mexico City. I would like to thank Eligio Calderon for helping to arrange the interview and Steve Wright and George Caffentzis for their advice and comments on this and earlier drafts.

${ }^{2}$ Bologna participated in Quaderni Rossi and Cronache Operaie in 1964, before founding Classe Operaia with Mario Tronti, Toni Negri and Romano Alquati. As an employee of Olivetti, he participated in the first attempts at unionising the new white-collar workers in electronics and data processing. In 1966, he began teaching at Trento University and contributed to Quaderni Piacentini. In late 1968 he edited the first two issues of Linea di Massa. With Negri, Oreste Scalzone, Franco Piperno, Mario Dalmaviva and others, he founded La Classe (1 May, 1969). In September 1969 Potere Operaio (Workers' Power) was founded; Bologna, Negri and Piperno made up its first national secretariat. In 1970, he became a professor of the History of the Workers Movement at Padua University, in the same department with Negri and Luciano Ferrari Bravo. In November, he left PO because of disagreements over the organisation's general policy. In 1972, with Negri he edited the first four volumes in Feltrinelli's "Marxist Materials" series. He founded Primo Maggio, a review of militant history, in 1973. During the 1970s he contributed to Sapere, a research journal involving militant workers and radical scientists, as well as to the three dailies of the Italian new left; Lotta Continua, Il Manifesto, Il Quotidiano dei Lavoratori. In 1978-79, he supported the policy of returning to "workers' centrality," the analysis of the large factories, and above all to the problems of the workers in the goods transportation sector (a specialism maintained up to the present). During the 1980s he lectured at Bremen University, where a unique group of Marxist social researchers, influenced by Italian workerism, had gathered. His "History of the Mass Worker" was published in Common Sense in 1992, when he cofounded the journal Altre Ragioni with Feruccio Gambino. During the 1990s he wrote much on the self-employed "autonomous worker" as an alternative to Negri's "immaterial worker" as the new social subject of this era. Biographical 
details from Bologna, "Workerist Publications and Bios," Italy: Autonomia Post-political Politics, Semiotext(e), Vol. 3, No. 3: 178-181.

${ }^{3}$ I agree with Lumley, States of Emergency: Cultures of Revolt in Italy from 1968 to 1978, (London 1990), on a preference for the use of the anglicised "operaism" and "operaist" rather than "workerism" and "workerist" "... since the English (version) carries certain pejorative connotations which the Italian term does not."

${ }^{4}$ Prior to the formation of POV-E in the mid Sixties, Toni Negri and other workerists "captured" the local Socialist Party (PSI) newspaper Progresso Veneto when Negri was still a PSI city councillor in Padua. Simultaneously, Negri's group within the PSI began to put out leaflets in local factories using the name "Potere Operaio" (Workers' Power). Negri left the PSI in protest against the formation of the first Centre-Left coalition government of the PSI and the Christian Democrats (DC) in 1964.

${ }^{5}$ The largest of the neo-Leninist groups which emerged from 1968-69, it was more moderate than the workerist Potere Operaio, concentrating on factory struggles at FIAT in Turin, anti-fascist activities and wider social struggles, such as the autoriduzione (self-reduction of transport tickets and household bills) campaigns of the early 1970s. Differently from the other groups, it also organised extensively in far less industrialised and urbanised Southern Italy, although one of its principle slogans was "Reclaim the city!" In 1972 it was thought to be behind the killing of Commissioner Calabresi, the senior Milan police officer generally considered to be responsible for the murder of the anarchist, Pinelli, falsely accused of the Piazza Fontana bomb in Milan in 1969 and thrown out of a fourth floor window of Milan's police headquarters. Its historic leader, Adriano Sofri, and two of his associates were arrested in 1987 and charged with the killing, on the word of a former comrade turned police informer. This cause celebre was even compared with the Dreyfus case in the Italian press, so flimsy or concocted was the evidence, until it finally closed in August 1999 with the acquital of the accused. In 1976 LC called on the New Left to tactically vote for the $\mathrm{PCI}$ in the national elections, a call which helped the $\mathrm{PCI}$ to almost overtake the $\mathrm{DC}$ as the largest party in parliament for the first time in its history. Unfortunately, the PCI did not repay the favour, voting for or. abstaining during crucial parliamentary votes which introduced an array of highly repressive legislation which had put many ex-LC militants in jail by the end of the decade and helped to defeat the autnomous social movements. LC dissolved itself at its final congress in Rimini in late 1976, when most of its women militants walked out in protest at its marshalls' (servizio di ordine) attack on a women's march in Rome the previous year, although its daily newspaper with the same name continued independently until the early 1980s. Many of its militants then became part of Autonomia and the 1977 Movement, while some of its marshalls took a militarist route, helping to form Prima Linea (Front Line), one of the major armed groups of the 1970s. 
${ }^{6}$ The term "autonomous" refers to groups who organised autonomously and felt themselves to be part of the broader Autonomia, but often maintained a distance from the "autonomi" (autonomists) of Organised Autonomia.

${ }^{7}$ Following the 1973 coup d'etat in Chile against Allende's elected socialist government, the PCI's leadership concluded that the parliamentary road to socialism was closed. Enrico Berlinguer, the PCI party secretary, devised the Historic Compromise strategy as a means of increasing support among the "ceti medi" (middle classes) as part of a more reformist social democratic programme. The severe political and economic crisis of the mid 1970s led the DC and PCI to agree a common strategy to restabalise the Italian state and organise social consensus for economic austerity measures. The Historic Compromise led the $\mathrm{PCl}$ from a position of benign neutrality in 1968 to open conflict with the radical social movements of 1977.

${ }^{8}$ See introduction to "Autonomia: Post-political Politics" (special issue), Semiotext(e) 3, no. 3 (1980).

${ }^{9}$ See Alberto Melucci, Challenging Codes: Collective Action in the Information Age, (Cambridge, UK 1996), particularly chapter 14.

${ }^{10}$ The Italian branch of British Leyland.

11 The founding father of Italian oral history, his study of grassroots factory militants of the 1950s and 1960s, his Militanti Politici di Base (Grassroots Political Militants) is a classic of modern Italian sociology. A conference on his work was held in November 1994 and an anthology was published in 1995. A more recent publication is Danilo Montaldi e la Cultura di Sinistra del Secondo Dopoguerra, (Naples, 1998).

12 The largest of the three Italian trade union confederations, it was linked to the Communist (PCI) and Socialist (PSI) parties. The CISL was associated with the Christian Democrats (DC), while UIL, the "yellow" confederation, was allied with the Republican and Liberal Parties, now defunct following the Tangentopoli (Kickback City) corruption scandals of the early 1990s.

${ }^{13}$ A Marxist sociological journal of the early 1960 s founded by Panzieri and Alquati in Turin, which set out to analyse the class composition of the new wave of factory militancy following the Piazza Statuto Revolt in Turin in 1962 through the use of Marx's "workers' enquiry." Many of the leading intellectuals of Italian workerism (a political and intellectual movement which held to the PCI's tenet of "workers centrality" but was otherwise critical of orthodox Marxism and the Historical Left) became involved in its editorial committee.

14 A movement mainly of students and unemployed youth, which impacted strongly on Italian politics, society and culture throughout 1977, before being repressed by the Historical Compromise regime of the PCI and DC. It represented the most intense period of activity of Autonomia (in its broadest sense) as a social movement.

${ }^{15}$ The result of a politically more radical split from Quaderni Rossi in 1962 by Tronti, Alquati, Negri and those who favoured a more interventionist role in 
factory struggles and from which the workerist organisation Potere Operaio developed in the late 1960s. The Piazza Statuto riots by strikers (the largest since 1945) in Turin of July 1962 which Panzieri denounced, along with the unions and the institutional Left, as the act of "provocateurs" and "fascists," led to the split.

${ }^{16} \mathrm{~A}$ workerist concept describing the new class composition in the factories of Northern Italy from the mid 1950 s, made up principally of young, unskilled and semi-skilled migrant assembly lineworkers from Southern Italy, who did not identify with the unions and the PCI and became the backbone of the autonomous workers struggles of the "Hot Autumn" of 1969. They contrasted with a previous generation of skilled "craft workers" (operaio artigiano) who were mainly North Italian and were the mainstay of the trade unions and the PCI. A further development of the concept of the "mass worker" by Toni Negri in the 1970s was the operaio sociale (socialised worker), an attempt to theorise the "new social subjects" of the post-1968 social movements; part-worker, partstudent, part-unemployed youth, part-feminist. It remains a more controversial and less well-defined social figure than the "mass worker."

${ }^{17}$ A reference to Magistratura Democratica, an organisation of radical judges who tried to oppose, or at least slow down and "democratise," the wave of repressive and anti-terrorist legislation that engulfed the autonomous social movements from the mid 1970 s onwards.

${ }^{18}$ Franco Basaglia, one of the founders of the Italian anti-psychiatry movement and the driving force behind Law 180 which ended the institutionalisation of the mentally ill, releasing them into community care. Tragically, this measure has been cynically copied globally and abused as a cost-cutting device by the neoliberal governments of the 1980s and 1990s. In Italy, underfunding of care in the community led to yet further marginalisation of the mentally ill.

${ }^{19}$ Nanni Ballestrini, poet, novelist and historian of the movements of the 1970s. His major works include Vogliamo Tutto! (We Want Everything!), an account of the Hot Autumn in Turin from the point of view of a South Italian worker at FIAT; Gli Invisibli (1987) (translated and published by Verso in 1989 as The Unseen), the story of a group of "autonomi" in the Milan hinterland around the time of the 1977 Movement; L'Orda d'Oro (1988, 1998, The Golden Horde), a history of the movements of 1968 to 1978, co-authored with Primo Moroni.

${ }^{20}$ The largest private chemicals company in Italy which was heavily involved in the web of corruption involving most of Italy's business and political classes, as revealed during the Tangentopoli scandals of the early 1990s.

${ }^{21}$ The Verdi (Greens) emerged as a political party which contested local and national elections from the mid 1980 s onwards. Composed of former New Left militants and a new generation of ecological activists who considered themselves "neither of the Left nor of the Right" and therefore objectively neutral in the class struggle. Initially, they had spectacular success at the electoral returns which they were unable to consolidate in the 1990 s, at the 
expense of alienating a large part of the organised labour movement, who saw them as a threat to their jobs and standard of living, and the radical social movements who considered them to be centrist opportunists, bereft of a serious analysis of the socio-economic and political causes of ecological and environmental decay.

${ }^{22}$ A workerist journal which took a more independent line on developments within the social movements and the class struggle of the 1970s than journals linked with Organised Autonomy such as Rosso (Red) or Senza Tregua (Without Respite).

${ }^{23}$ Pietro Calogero, a magistrate (investigating judge) in Padua linked to the $\mathrm{PCI}$, arrested and charged Toni Negri and most of the intellectuals and academics associated with Organised Autonomy with terrorism and attempted subversion of the state, on 7 April 1979. His theorem was that Autonomia Organizzata was the "brains" behind the Red Brigades (BR), that the two organisations were one and the same, and that Negri and others in Autonomia were the "intellectual authors" of the kidnapping and murder of Aldo Moro, the former DC prime minister, in 1978. Eventually, the accused were able to prove that the theorem was unfounded and little more than an excuse for a witch hunt of the extraparliamentary Left and in particular Autonomia. Autonomia had always attacked the BR as a crudely anachronistic, Marxist-Leninist throwback to the "Partigiani" (Partisans) of World War Two, which only played into the hands of the state. Reactions varied from the ambiguous ("They are comrades who have got it wrong") to Negri's "syphillis of the movement." In fact, relations between BR and Autonomia political prisoners were strained, to say the least. Charges were eventually reduced to forming ill-defined "armed groups" (banda armata) and most of the accused had been acquitted by 1985 . Some had been held in preventive detention without being tried for five years or more, a situation which led to a campaign by Amnesty International and other human rights organisations. Negri was elected to parliament as a Radical Party candidate, released from prison under parliamentary immunity and escaped to France just before parliament voted to remove his immunity from prosecution in 1983 . There he joined a growing community of Italian political exiles who had fled from the worst wave of repression since Fascism, with thousands being thrown into "special prisons" on the word of "pentiti" (repentant ex-militants). Negri continued his academic and political career in Paris, having been invited by Althusser to teach at the Ecole Normale, and helping to edit Futur Anterieur, until voluntarily deciding to return to Italy in 1997 to serve out the remainder of his sentence and campaign for a general amnesty for Leftist political prisoners. $\mathrm{He}$, along with several Autonomia and over $100 \mathrm{BR}$ and other political prisoners, plus some 200 political exiles, still await the long-promised but slow to materialise "political solution" to the "Years of Lead" of the late 1970s and early 1980 s. 